\title{
The use of laser interferometer to study the texture and wear of a preserved blades material
}

\author{
A. Djeffal*, M. Bounazef**, E. A. Adda bedia*** \\ *Mechanical department, LMH, University of Sidi Bel Abbes, Algeria, BP 89, E-mail: djeffalal@yahoo.fr \\ **Mechanical department, LMH, University y of Sidi Bel Abbes, Algeria, BP 89, E-mail: bounazef@yahoo.com \\ ***Civil engineering department, LMH, University of Sidi Bel Abbes, Algeria, BP 89, E-mail: addabed@yahoo.fr \\ crossref http://dx.doi.org/10.5755/j01.mech.17.4.577
}

\section{Introduction}

$\mathrm{BN}-\mathrm{AlCrNi}$ material deposited by atmospheric plasma spraying process is used as a gasket. In contact with the turbine blades, it tears off easily protecting them against wear. During this friction, two phenomena may occur. The first one is the blade wear; the second one is the material transfer of the layer towards the blade tip. Neither one nor the other is desirable during the working. They must be avoided and moved up because they cause a malfunction and power loss of the machine. The transfer of the $\mathrm{BN}-\mathrm{AlCrNi}$ on the blade tip shapes an unbalance. With the very high rotation speed of the wheel, the unbalance causes major vibrations that reach the threshold of the alarm and stopping of the machine. Unlike, the wear of the blades causes a running clearance between the impeller and the seal causing leak of flue gases; there are losses of energy, drop in efficiency and effectiveness and great fuel consumption. One alternative to avoid these troubles is to simulate what happens on a gas turbine during the friction by using an abradability test bench (Fig. 1).

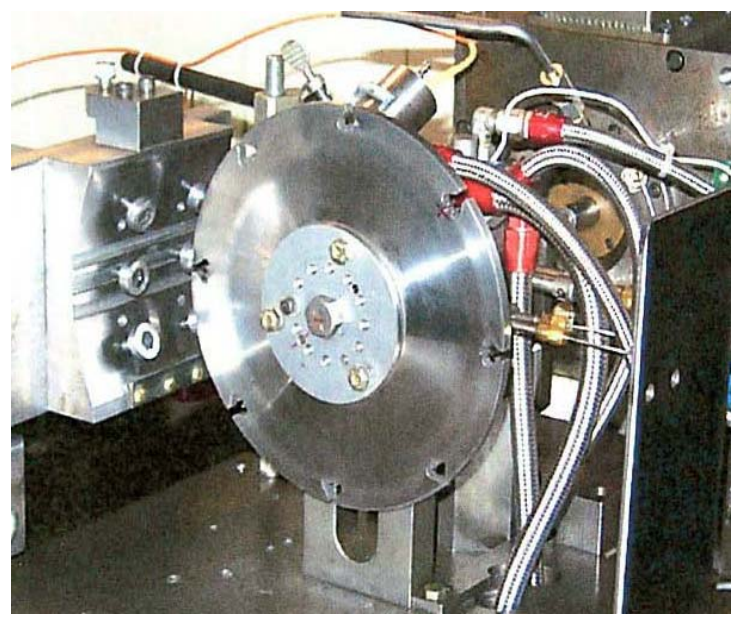

Fig. 1 An abradability test bench

Three important parameters may be considered, witch all affect surface of the sprayed layer, the material texture and grains sense. These are linear speed of wheel rotation, the velocity of blade incursion into the layer of material and incursion depth of the blade in the coating. These last parameters act directly on the friction [1] and the wear blade, tearing and displacement of the material, surface texture and obtained roughness. By changing these 3 parameters, we adjust our experiments in order to complete the set of unconventional experiments design. Analysis of the experimental results allows us to have a clear view of the action of each parameter on the wear of the material and texture of its surface by obtaining 2D and $3 \mathrm{D}$ graphs. They give us detailed information on the occurred phenomena during contact between the blades and material.

\section{Measurement of roughness by laser interferometer}

The laser interferometer used (Fig. 2) allows measurement at the surface roughness without contact. This avoids the roughness modification caused by altercation.

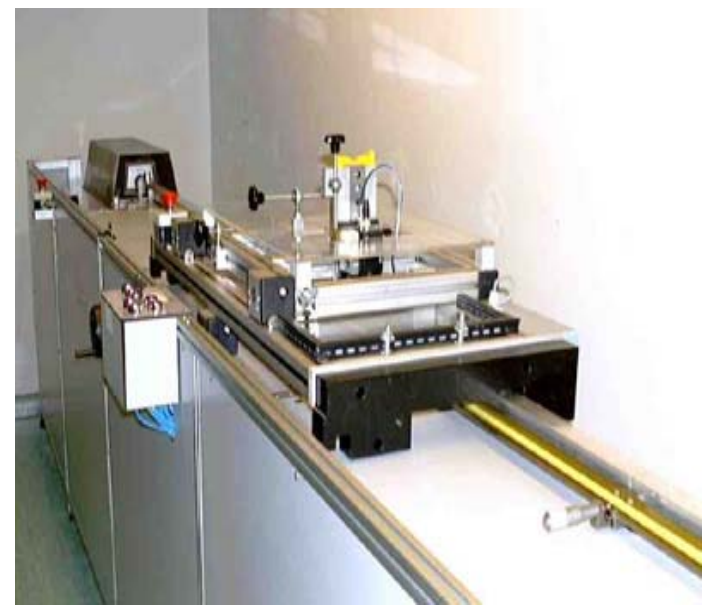

Fig. 2 The laser interferometer

With this measuring device, we obtain the values of three parameters characterising roughness and surface topography by double sweeps in width and length of the surface. The software allows us to trace the profile and texture of the surface in 3 dimensions. The theory on which bases the $3 \mathrm{D}$ roughness is similar to $2 \mathrm{D}$ theory; the difference resides in the double measures; we begin to sweep by displacement of the laser beam, the length then the width of the surface. The formulas of roughness parameters are expressed by the double sums terms [2-4].

\subsection{Parameter definition of roughness in 3 dimensions}

$S_{a}$ is arithmetic average of deviations from the average value (equivalent to the $R_{a}$ in 2 dimensions). It characterizes roughness of the surface, if this value is important, the ridge of the roughness is important.

$$
S_{a}=\frac{1}{N_{X} N_{Y}} \sum_{X=0}^{N_{X}-1} \sum_{Y=0}^{N_{y}-1}\left|Z_{X, Y}\right|
$$


where $Z_{X, Y}$ is the difference between the height of the point of coordinates $(x, y)$ and the average plan; $N_{X}$ is number of sampled points in the direction $\mathrm{X} ; N_{Y}$ is number of sampled points in the direction $\mathrm{Y}$.

The absolute value of $Z_{x, y}$ in Eq. (1) shows some points may have a negative value (in valleys).

\subsection{Fabrication of coatings and topography measurement}

Sixteen samples of $\mathrm{BN}-\mathrm{AlCrNi}$ coating are designed by the same spraying parameters in our study [5]. We use the operating conditions of atmospheric plasma spraying: Argon flow is 45 SPLM, Hydrogen flow is 5 SPLM, electrode voltage is $55 \mathrm{~V}$, current intensity is $550 \mathrm{~A}$, plasma power is $40 \mathrm{~kW}$, spraying distance is $120 \mathrm{~mm}$ and flow powder is $40 \mathrm{~g} / \mathrm{min}$. During spraying, the powder in the form of molten droplets is plated on the sample forming the successive layers. Before the second layer is sprayed, the first is cooled by a flow of fresh air directed to the coating. The obtained coating must present a consensus between the low surface hardness and the good resistance to erosion, so that the coating should not be torn off easily by tiny bodies, and must be relatively tender for not causing significant blades wear [6-8]. On these samples, we carry out the abradability tests by changing 3 working parameters. These are the incursion velocity in microns by second, the incursion depth in microns and linear speed of the wheel at constant temperature of $500^{\circ} \mathrm{C}$. In order to carry out behaviour tests on protective porous material to deduce their behaviour with the various factors, one uses machine which reproduce the turbine working. This equipment must be able to simulate thermal expansion of the turbine parts, the velocity of the parts dilation and rotation of the rotor blades $[9,10]$. We use manufacturing tool machine with numerical control. It comprises a wheel on which the blades (Al: $6.75 \% ; \mathrm{V}: 4.50 \%)$ are fixed and turns at the desired speed. The rotor movement is given by an asynchronous electric motor. It enables us to obtain linear speed $\left(V_{\text {lin }}\right)$ between the blades and the protective porous seal. Thermal stator dilatation and expansion of the rotor blades are given by an electrical stepper motor. With this stepper motor, we can adjust the incursion velocity $\left(V_{\text {inc }}\right)$ within the protective porous coating and the incursion depth $\left(D_{i n c}\right)$ inside the spraying material. These parameters are put up directly on board and displayed on the working tool machine. The test rig is equipped with a thermometer; it measures temperature of the coating and the cutting sensor measures the tangential wrenching stress of the coating particles caused by blades friction on the material. To regulate the temperature, we use an oxyacetylene blowpipe flame directed to the seal material. We note that this kind of material is used on the turbines to replace air-tight plates. When this material is deposited and scraped by blades, it creates an optimum gap between the blades and the coating that does not allow the passage of combustion gas. It is characterised by the properties already obtained in previous studies [11-13]. Concerning the parameters of the coating roughness, the results are given directly by the software of the machine; the graduated ruler (Table 1).

As the method of experimental designs [14-17],
Table 1

Parameters of coating roughness

\begin{tabular}{|c|c|c|c|c|}
\hline $\mathrm{N}^{\circ}$ & $\begin{array}{c}\text { Incursion } \\
\text { velocity, } \\
\mu \mathrm{m} / \mathrm{s} \\
\left(x_{1}\right)\end{array}$ & $\begin{array}{c}\text { Linear speed, } \\
\mathrm{m} / \mathrm{s}\end{array}$ & $\begin{array}{c}\text { Incursion } \\
\text { depth, } \\
\mu \mathrm{m}\end{array}$ & $\begin{array}{c}S_{a}, \\
\mu \mathrm{m}\end{array}$ \\
\hline 1 & 760 & 153 & 289 & 61.5 \\
\hline 2 & 2.5 & 305 & 543 & 93.4 \\
\hline 3 & 138 & 305 & 1478 & 25.4 \\
\hline 4 & 760 & 153 & 822 & 41.9 \\
\hline 5 & 138 & 305 & 1330 & 34.1 \\
\hline 6 & 760 & 153 & 970 & 37.8 \\
\hline 7 & 2.5 & 305 & 1000 & 40.9 \\
\hline 8 & 760 & 153 & 594 & 48.3 \\
\hline 9 & 500 & 250 & 379 & 115.4 \\
\hline 10 & 100 & 397 & 525 & 37.2 \\
\hline 11 & 10 & 397 & 475 & 34.3 \\
\hline 12 & 100 & 397 & 525 & 37.3 \\
\hline 13 & 10 & 397 & 525 & 26 \\
\hline
\end{tabular}

requires codification of the factors levels, one takes the maximum value coded " +1 ", and the minimal value coded " 1 ". The intermediate values must be between -1 and +1 , i.e. the factor must be in the interval $[-1,+1]$. As all factors take several levels, and are expressed in different units, it is necessary to carry out standardisation; we obtain the coded value valid for all factors values with the following relation

$$
x_{i}=\frac{u_{i}-\left(\frac{u_{\min i}+u_{\operatorname{maxi}}}{2}\right)}{\left(\frac{u_{\operatorname{maxi}}-u_{\min i}}{2}\right)}
$$

where $u_{\min }$ is the lower level limit of factor; $u_{\max }$ is the upper level limit of factor; $u_{i}$ is the value on which one carries out coding value and $x_{i}$ represent the coded value of factor.

\section{Modelling by designs of experiments}

The mathematical analysis consists in estimating of the response by the method of least squares. The polynomial is second degree form. We want to decrease the number of coefficients because the higher degree engenders the more complex polynomial without precision. The squared terms are generally enough to show the surface curves. The general form of the polynomial function is

$$
y_{i}=a_{0}+\sum_{i=1}^{k} a_{i} x_{i}+\sum_{i=1}^{k} a_{i i} x_{i}^{2}+\sum_{i=1}^{k-1} \sum_{j=j+1}^{k} a_{i j} x_{i} x_{j}
$$

The developed form of the expression with 9 terms obtained with 3 parameters is

$$
y_{i}=a_{0}+a_{1} x_{i, 1}+a_{2} x_{i, 2}+a_{3} x_{i, 3}+a_{12} x_{i, 1} x_{i, 2}+a_{13} x_{i, 1} x_{i, 3}+a_{23} x_{i, 2} x_{i, 3}+a_{11} x_{i, 1}^{2}+a_{22} x_{i, 2}^{2}+a_{33} x_{i, 3}^{2}
$$



pression

The coefficients are found by the following ex-

Coefficients $=\left({ }^{t} X X\right)^{-1}\left({ }^{t} X\right)(Y)$
For $S_{a}$, the values of coefficients are given in Table 2 . We choose $S_{a}$ in this study, because it is the more important parameter between others.

Table 2

Coefficients value of Eq. (4)

\begin{tabular}{|c|c|c|c|c|c|c|c|c|c|}
\hline$a_{0}$ & $a_{1}$ & $a_{2}$ & $a_{3}$ & $a_{12}$ & $a_{13}$ & $a_{23}$ & $a_{11}$ & $a_{22}$ & $a_{33}$ \\
\hline 95.9063 & 11.0161 & -15.1978 & -24.284 & 17.3788 & 23.6772 & 14.3335 & -7.97384 & -25.7226 & 2.77683 \\
\hline
\end{tabular}

$$
\begin{aligned}
& \text { Now, the Eq. (4) is } \\
& y=95.9063+11.0161 x_{1}-15.1978 x_{2}-24.2840 x_{3}+ \\
& +17.3788 x_{1} x_{2}+23.6772 x_{1} x_{3}+14.3335 x_{2} x_{3}- \\
& -7.97384 x_{1}^{2}-25.7226 x_{2}^{2}+2.77683 x_{3}^{2}
\end{aligned}
$$

The coefficient of quality $R^{2}$ is a measure of fitness. A large $R^{2}$ is a necessary condition for a good model, but it is not sufficient. We can have poor models (models that cannot predict) with a large $R^{2}$. This is particularly true when we have few degrees of freedom for the residuals. We will get a poor $R^{2}$ when we have poor reproducibility (poor control over the experimental error) or poor model validity (the model is incorrect). The predictive quality designed by $Q^{2}$ tells us how well the model predicts new data. A useful model should have a large $Q^{2}$. We get a poor $Q^{2}$ when we have poor reproducibility (poor control over the experimental error) or/and poor Model validity (the model is incorrect). When we have a good $R^{2}$, moderate model validity, and a design with many degrees of freedom of the residuals, then a poor $Q^{2}$ is usually due to insignificant terms in the model. In our model $R^{2}$ and $Q^{2}$ of polynomial are close to 1 , and then we have a good model (Fig. 3).

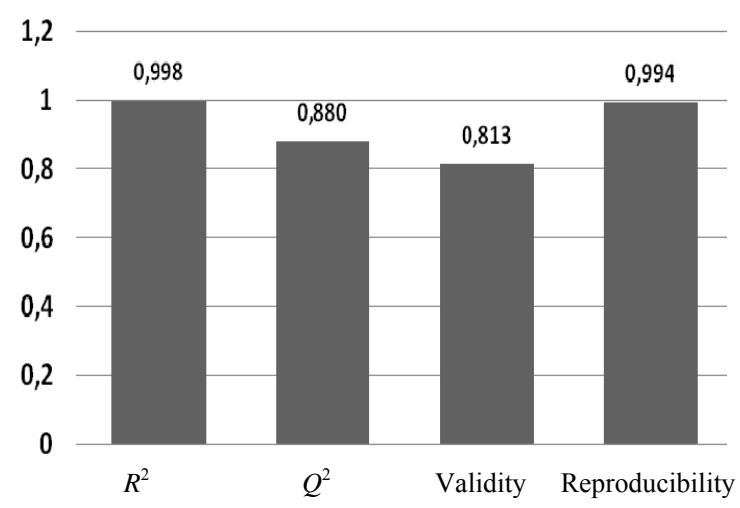

Fig. 3 Parameters bars of model

When the model validity bar is larger than 0.25 , there is no lack of fitness of the model (the model error is in the same range as the pure error). A model validity bar of 1 represents a perfect model. When the model validity is less than 0.25 , the model error is significantly larger than the pure error (reproducibility). When the reproducibility bar is 1.0 , the error is 0 . This means that under the same conditions the response values are identical. When the reproducibility bar is 0 , the pure error equals the total variation of the response. If we have reproducibility above 0.8 , the replicated experiments have been performed at different time points and that each time the experimental setup is started from scratch. If the reproducibility is below 0.5 , we have a large pure error, poor control of the experimental set up (the noise level is high), and we cannot assess the validity of the model. These results in low $R^{2}$ and $Q^{2}$ we should improve the reproducibility.

\section{Interpretation of experiments results and discussion}

Fig. 3 shows that everything we have said is verified; it proves that the model is correct and acceptable for $S_{a}$. In addition to the 4 parameters mentioned above which show that the model is good, we notice in Fig. 4 that there are no large deviations between measured values and predicted values of model (Eq. (6)).

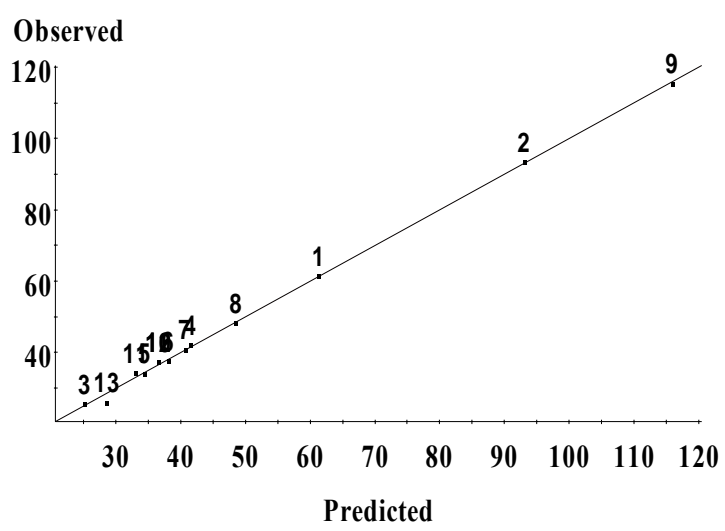

Fig. 4 Deviations between observed and predicted values

The points are close to the line of $45^{\circ}$. The small value of difference is in experiment number 3 , it is equal to 0.2066 and the great value is -2.6407 at experiment 13 . Following the blade movement, we see different textures that define surfaces in which the grains are oriented differently (Fig. 5). In Fig. 5, the striations are parallel to the movement of blades and form on the surface of the coating an obstacle which prevents the combustion gases which run perpendicular to the grooves.

This gas escapes between the blade and the coating. In this first case, when the blade rubs on the coating, the surface is machined and there is no tearing of the BN$\mathrm{AlCrNi}$ by blades. They are generally obtained when the incursion depth of the blade in the coating is low and the incursion velocity is high (experiment 1: $S_{a}=61.5 \mu \mathrm{m}$ and experiment 9: $\left.S_{a}=115.4 \mu \mathrm{m}\right)$. In Fig. 6 , the striations are orthogonal to the blades movement, thus they form passages headed in the direction of gas movement. They flow easily; it is in this case the loss of efficiency and effectiveness because these gases do not participate in the power production of the turbine.

When the incursion depth is great and the incursion velocity is small, there is coating tearing and formation of orthogonal striations (experiment 3: $S_{a}=25.4 \mu \mathrm{m}$, 


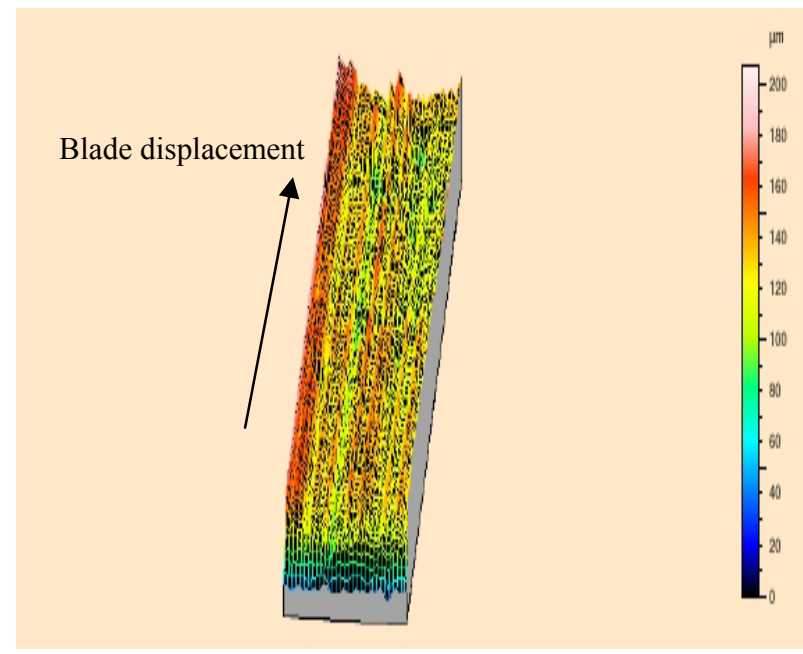

Fig. 5 Parallel striations of texture

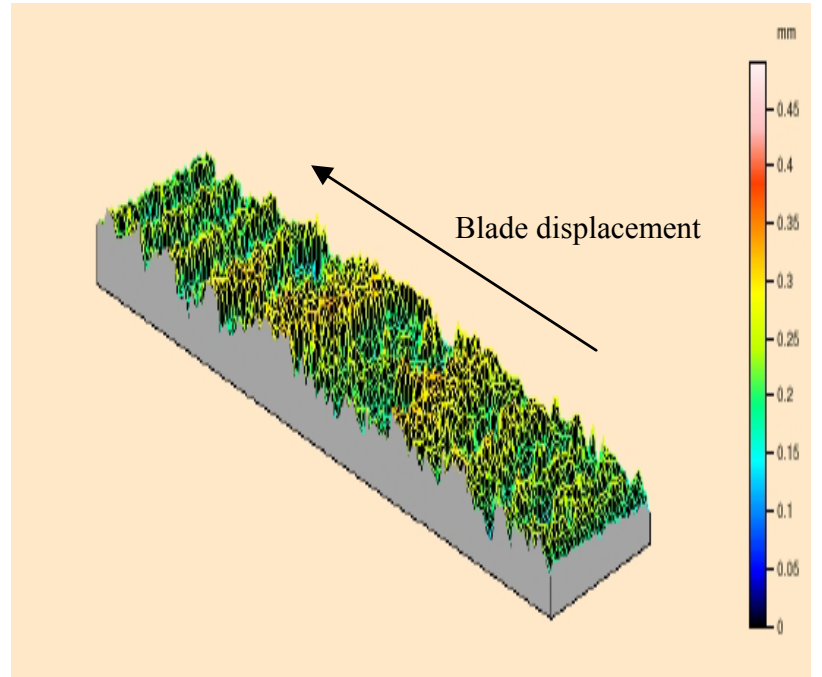

Fig. 6 Orthogonal striations of texture

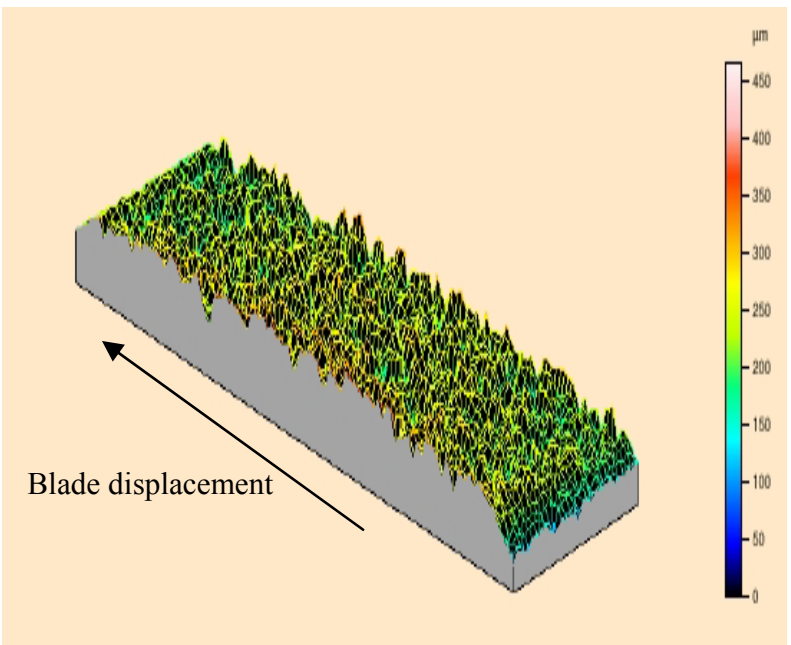

Fig. 7 Presence of holes

experiment 5: $S_{a}=34.1 \mu \mathrm{m}$, experiment 7: $S_{a}=40.9 \mu \mathrm{m}$ ). At the same time, this tearing of the coating causes displacement of the material towards top of the blade; there is no blade wear but its length increases. The respective values of the length increase are $w=-178 \mu \mathrm{m}, w=-30 \mu \mathrm{m}$, $w=0 \mu \mathrm{m}$ (The minus sign indicates the elongation of the blade by coating displacement; the plus sign indicates the blade wear in Table 1). The displacement phenomenon of the coating causes unbalance on the rotor of the turbine, it creates vibrations. The last type of surface texture is shown in Fig. 7.

We note here that there is appearance of holes on the surface, because here too, there is grubbing of metal. This provides a seal in the form of cells of honeycomb. This type of joint provides a good seal; the gas combustion is slowed down during this movement. The 3 types of surfaces depend also on the reached temperature on the coating surface during the friction with the blade during incursion and rotation of the turbine wheel. The studies of several authors have shown that the temperature can reach $1170 \mathrm{~K}$ on the coating surface [18]. By analysing Eq. (6), one can easily see that the most important factor which affects the response $y$, i.e. on the value of arithmetic average of deviations $S_{a}$, is the polynomial coefficient 24.2640; it decreases the response $y$. Taking into account the interaction between the parameters (Incursion velocity designated by $x_{1}$ in model (Eq. (6)), linear speed designated by $x_{2}$ and incursion depth designated by $x_{3}$ ), we found that the polynomial coefficient +23.6772 acts considerably compared to others, i.e. the interaction between incursion velocity and incursion depth increases the value of $S_{a}$. Fig. 8 shows what is the effect who acts positively or negatively on the value $S_{a}$.

In Fig. 8, the effect are sorted from the largest to the smallest; it shows the effect of each parameter or their interaction on the response $y$. We see now how each pa-

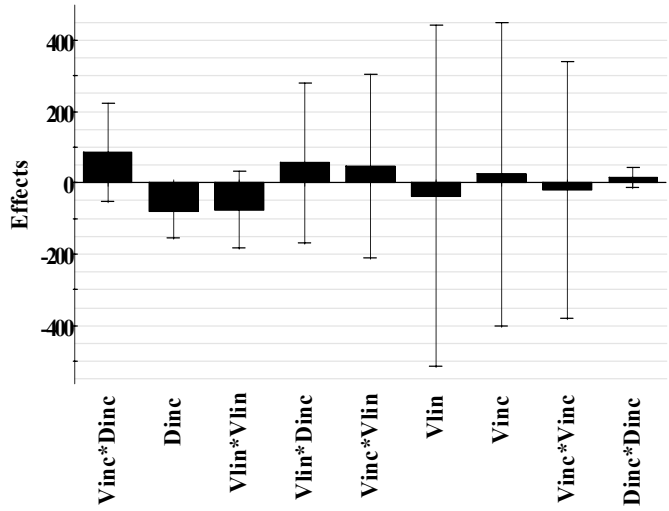

Fig. 8 Parameters effects of $S_{a}$

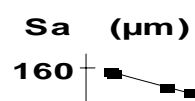

80

o

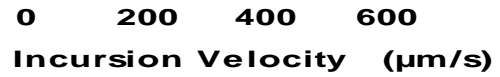

Fig. 9 Parameters action on $S_{a}$ with low parameter $\left(V_{\text {inc }}=\right.$ $=2.5 \mu \mathrm{m} / \mathrm{s}$ )

rameter acts on the roughness i.e. $S_{a}$ value. The 3 series of graphs in Figs. 9-17 describe the effect of the incursion velocity $x_{1}$, the linear speed $x_{2}$ and the incursion depth $x_{3}$ on $S_{a}$ by varying one of them and leaving the 2 other with- 
out variation. For this, we have chosen 3 constant values of these parameters; the minimum value, the centre value and the maximum value. We note that for the 3 low values $\left(V_{\text {inc }}=2.5 \mu \mathrm{m} / \mathrm{s}, V_{\text {lin }}=153 \mathrm{~m} / \mathrm{s}, D_{\text {inc }}=289 \mu \mathrm{m}\right)$.

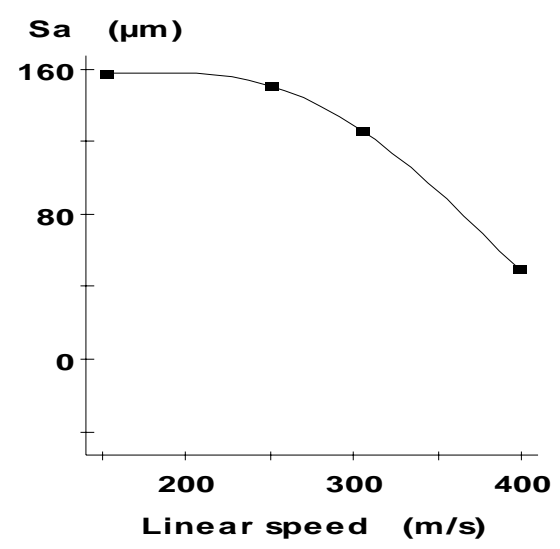

Fig. 10 Parameters action on $S_{a}$ with low parameter $\left(V_{\text {lin }}=153 \mathrm{~m} / \mathrm{s}\right)$

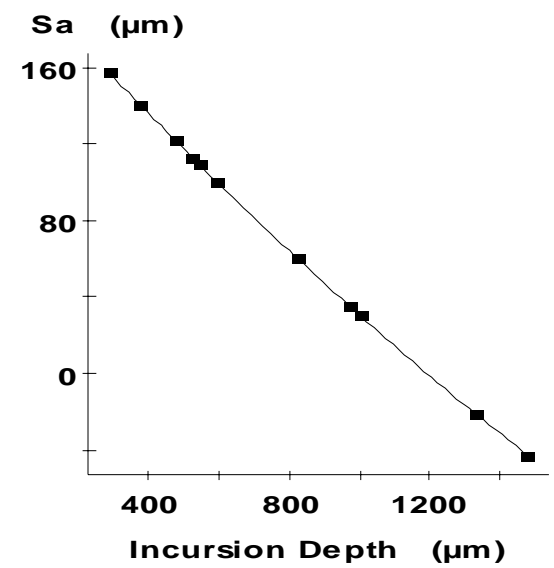

Fig. 11 Parameters action on $S_{a}$ with low parameter $\left(D_{\text {inc }}=\right.$ $=289 \mu \mathrm{m})$

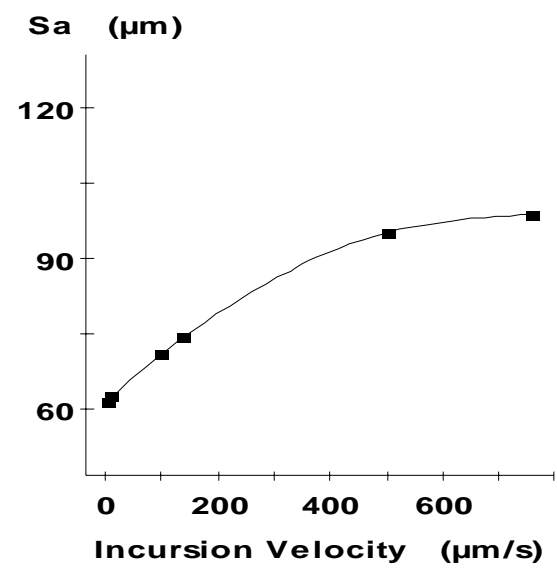

Fig. 12 Parameters action on $S_{a}$ with centre parameter $\left(V_{\text {inc }}=381.25 \mu \mathrm{m} / \mathrm{s}\right)$

The increased 3 parameters reduce surface roughness of the coating since one reach $60.9 \mu \mathrm{m}$ for $V_{\text {inc }}$ of $760 \mu \mathrm{m} / \mathrm{s}$ (Fig. 9), $50.5 \mu \mathrm{m}$ for $V_{\text {lin }}$ of $397 \mathrm{~m} / \mathrm{s}$ (Fig. 10) and $-43.3 \mu \mathrm{m}$ for $D_{\text {inc }}$ of $1478 \mu \mathrm{m}$ (Fig. 11). For the centre values $\left(V_{\text {inc }}=381.25 \mu \mathrm{m} / \mathrm{s} ; \quad V_{\text {lin }}=275 \mathrm{~m} / \mathrm{s} ; \quad D_{i n c}=883.5 \mu \mathrm{m}\right)$, the behaviour differs because when $V_{\text {inc }}$ increases, the roughness increases up to $99 \mu \mathrm{m}$ (Fig. 12).
The curve number 13 is composed of 3 phases; An ascending phase (increasing), a peak and a descending phase (decreasing). When $V_{\text {lin }}$ increases, the roughness reaches a peak of $91 \mu \mathrm{m}$ for $V_{\text {lin }}=271 \mathrm{~m} / \mathrm{s}$ and comes down until the value of $51.3 \mu \mathrm{m}$ (Fig. 13).

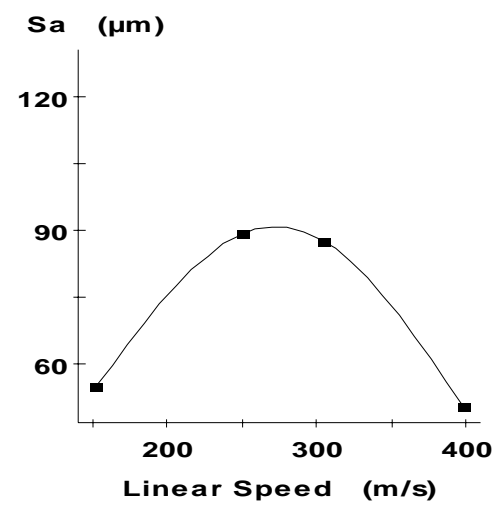

Fig. 13 Parameters action on $S_{a}$ with centre parameter $\left(V_{\text {lin }}=275 \mathrm{~m} / \mathrm{s}\right)$

On the order hand, when $D_{\text {inc }}$ takes its maximum value of $1478 \mu \mathrm{m}$, the roughness $S_{a}$ decreases to $68.5 \mu \mathrm{m}$ (Fig. 14).

In the case of high values of 3 parameters $\left(V_{\text {inc }}=\right.$ $\left.=760 \mu \mathrm{m} / \mathrm{s}, V_{\text {lin }}=397 \mathrm{~m} / \mathrm{s}, D_{\text {inc }}=1478 \mu \mathrm{m}\right)$, one remarks with their increase, the value of $S_{a}$ increases too. It reaches the same value in 3 cases of $132 \mu \mathrm{m}$ (Fig. 15) for $V_{i n c}=$ $=760 \mu \mathrm{m} / \mathrm{s}$.

We remark again the value of $132 \mu \mathrm{m}$ of $S_{a}$ for $V_{\text {lin }}=397 \mathrm{~m} / \mathrm{s}$ (Fig. 16) and for $D_{\text {inc }}=1478 \mu \mathrm{m}$ (Fig. 17).

We study also the interactions between the parameters (Fig. 8). We represent 2 parameters on 2 different

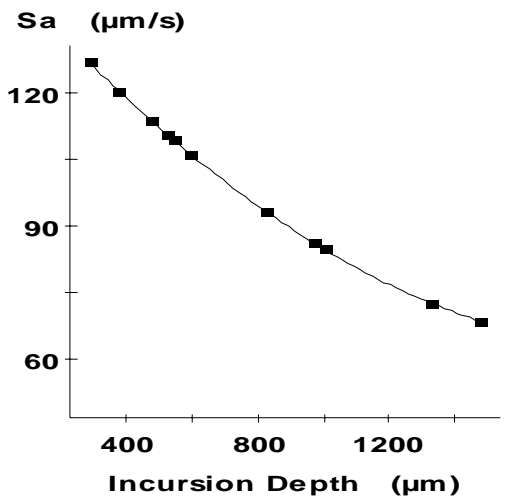

Fig. 14 Parameters action on $S_{a}$ with centre parameter $\left(D_{\text {inc }}=883.5 \mu \mathrm{m}\right)$

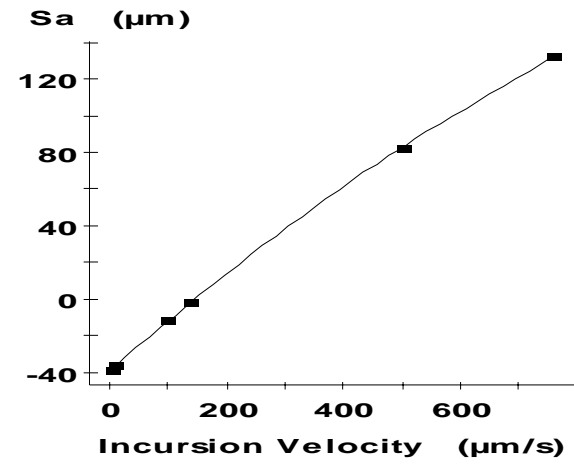

Fig. 15 Parameters action on $S_{a}$ with high parameters $\left(V_{\text {inc }}=760 \mu \mathrm{m} / \mathrm{s}\right)$ 


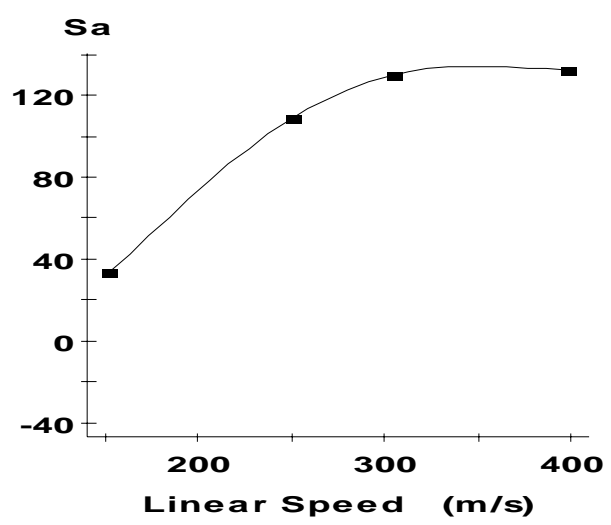

Fig. 16 Parameters action on $S_{a}$ with high parameters $\left(V_{\text {lin }}=397 \mathrm{~m} / \mathrm{s}\right)$

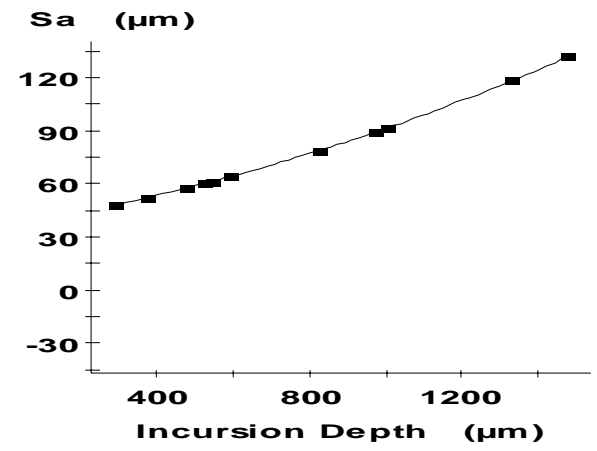

Fig. 17 Parameters action on $S_{a}$ with high parameters $\left(D_{\text {inc }}=1478 \mu \mathrm{m}\right)$

axis keeping the third $\left(D_{\text {inc }}\right)$ constant. On the third axis the response $S_{a}$ is represented. The analysis of 3 cases (from Fig. 18 until Fig. 23) of responses surfaces and contours, gives us the following comments: we note that the area where the roughness is large (between 140 and $180 \mu \mathrm{m}$ ) is available for low values of $V_{\text {inc }}$ and $V_{\text {lin }}\left(V_{\text {inc }}=0 \mu \mathrm{m} / \mathrm{s}\right.$ until $200 \mu \mathrm{m} / \mathrm{s} ; \quad V_{\text {lin }}=150 \mathrm{~m} / \mathrm{s}$ until $275 \mathrm{~m} / \mathrm{s}$ ) when $D_{\text {inc }}=$ $=289 \mu \mathrm{m}$ (Figs. 18 and 19).

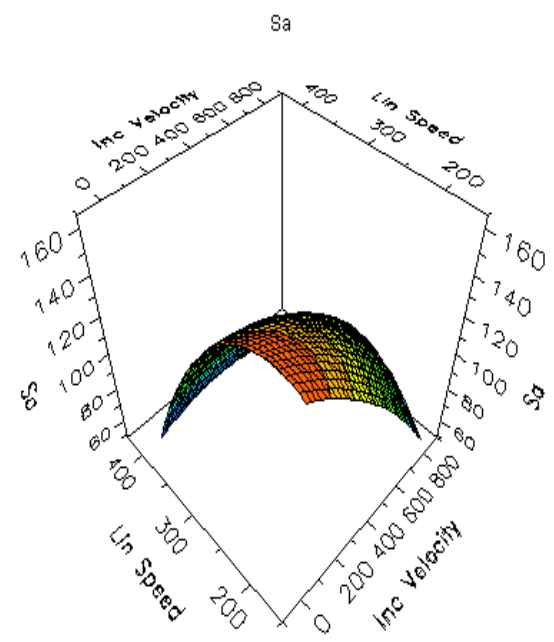

Fig. 18 The response surface of $S_{a}$ with $D_{i n c}=289 \mu \mathrm{m}$

In Figs. 20 and 21, we see that the simultaneous increase of the incursion velocity from 0 until $750 \mu \mathrm{m} / \mathrm{s}$ and linear speed from 150 until $400 \mathrm{~m} / \mathrm{s}$ increases the $S_{a}$. A great value is obtained when $V_{\text {inc }}$ reaches $650 \mu \mathrm{m} / \mathrm{s}$ and $V_{\text {lin }}$ varies between 275 and $340 \mathrm{~m} / \mathrm{s}$; the value of $S_{a}$ exceeds $100 \mu \mathrm{m}$.

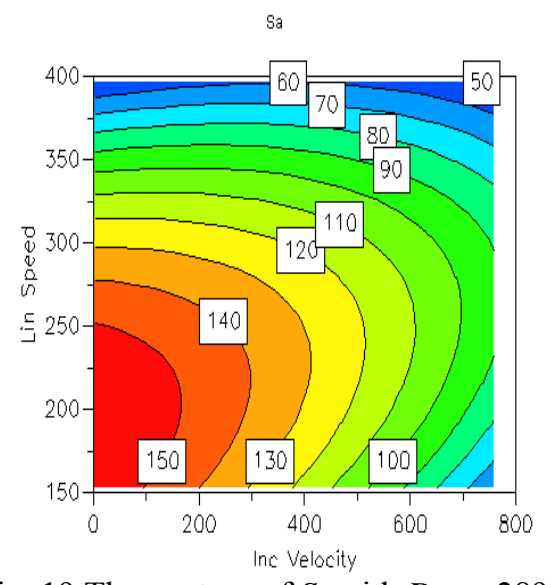

Fig. 19 The contour of $S_{a}$ with $D_{\text {inc }}=289 \mu \mathrm{m}$

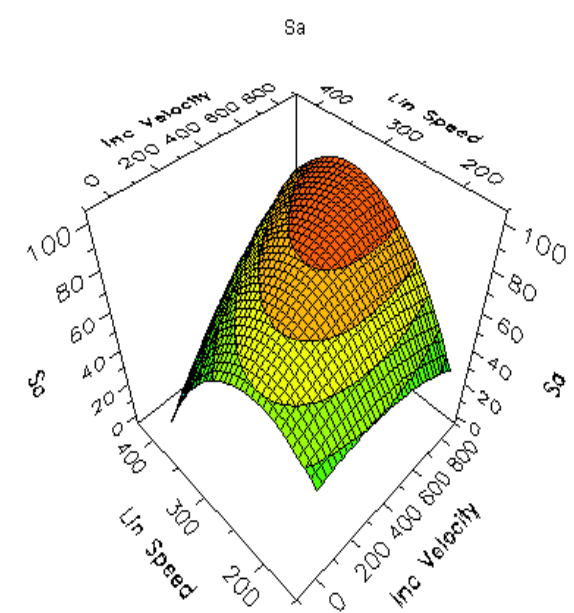

Fig. 20 The response surface of $S_{a}$ with $D_{\text {inc }}=883.5 \mu \mathrm{m}$

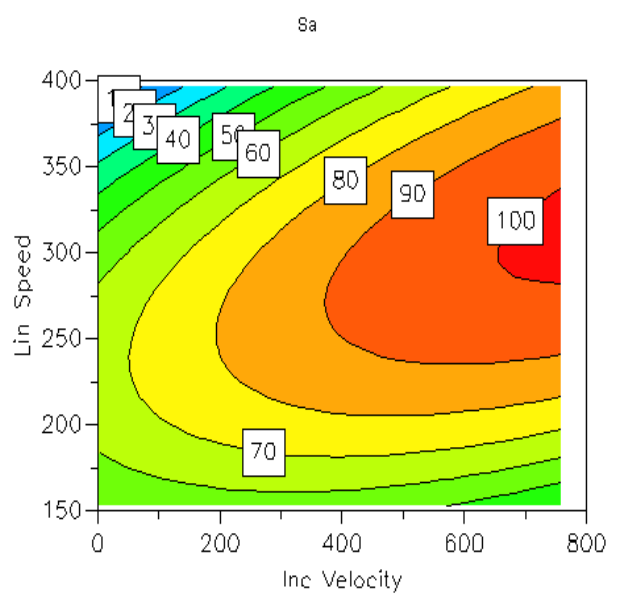

Fig. 21 The contour of $S_{a}$ with $D_{i n c}=883.5 \mu \mathrm{m}$

The lowest roughness $S_{a}(0 \mu \mathrm{m})$ is obtained when $D_{\text {inc }}=1478 \mu \mathrm{m}$, between $V_{\text {inc }}=0 \mu \mathrm{m} / \mathrm{s}$ and $V_{i n c}=325 \mu \mathrm{m} / \mathrm{s}$ with $V_{\text {lin }}$ situated between 150 and $400 \mathrm{~m} / \mathrm{s}$ (Figs. 22 and 23). Broadly speaking, the simultaneous increase of $V_{i n c}$ and $V_{\text {lin }}$ decreases the roughness when the $D_{\text {inc }}$ is low $(289 \mu \mathrm{m})$; but when $D_{i n c}$ is centre $(883.5 \mu \mathrm{m})$ or high $(1478 \mu \mathrm{m})$, this leads the increase of $S_{a}$.

To observe the action of 3 parameters at the same time, it is necessary to refer to equation 6 in which all parameters and all interactions between them are considered. If we want to have the value of $S_{a}(y)$ equal to zero, we predefine for example 2 parameters and then we obtain the 


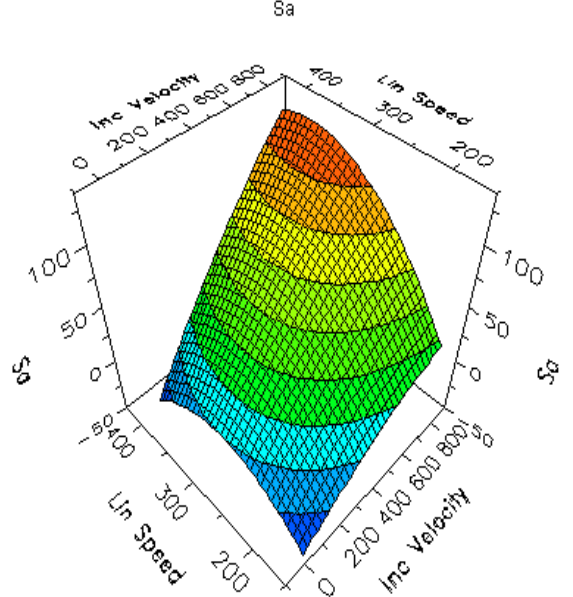

Fig. 22 The response surface of $S_{a}$ with $D_{i n c}=1478 \mu \mathrm{m}$

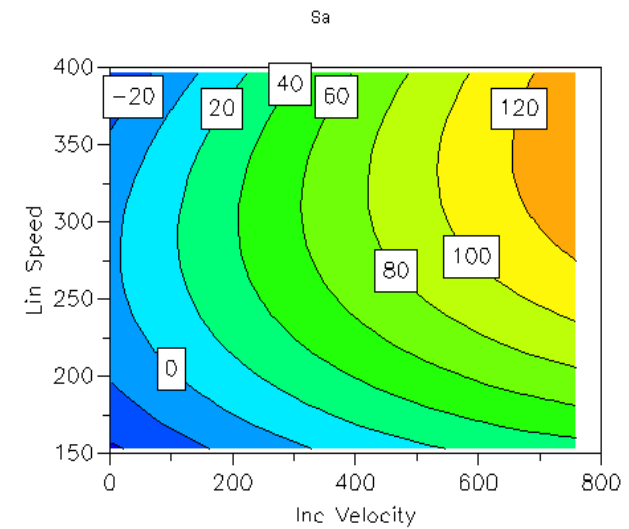

Fig. 23 The contour of $S_{a}$ with $D_{\text {inc }}=1478 \mu \mathrm{m}$

value of the third parameter from the Eq. 6. This equation can provide several solutions to the zero response because the 3 parameters are interdependent. Of course, this is valid for any value of $y$.

\section{Conclusions}

The broad study of BN-AlCrNi finding operating parameters that limit the blade wear, generate surface roughness of the coating close to zero, create a surface texture of good orientation of cooled splats and grains facilitating the flow of exhaust gases, prevent the material transfer from the coating towards tips of the blades, is relatively difficult. This is due to complexity of the phenomena that occur; they are often dependent. There are cases where a parameter improves roughness but creates unbalance of the rotor, where the texture is favourable to gas flow but produces a bad surface texture which does not favour the creation of the joint between the blade and coating. We must also take into account the temperature reached during the friction and the generated stress, exceeding of the limits cause damages. But often there are cases where there is a consensus that includes the parameters close to the ideal parameters that give satisfaction and limit the harmful phenomenon. This material on which the experiments were conducted in the laboratory is still not used on real turbines because the real test must be done, as the action of moisture on his grip, the effect of resonance sound, the material ageing and many other experiments.

\section{References}

1. Svetnickienè, V.; Čiukas, R. 2009. Investigation of friction properties of yarns from natural fibres, Mechanika 1(75): 73-77.

2. Whitehouse, D.J. 2002-2006. Surface and Nanometrology, Taylor and Francis. 1150p.

3. Bharat Bhushan. 2009. Micro/NanoTribology, Joemuscat. 859p.

4. Thomas, Tom. R. 1999. Rough Surfaces, second edition, 2 Sub editions, March 15, 1999, World Scientific Publishing Company. 278p.

5. Zdravecka, E.; Suchanek, J.; Tkacova, J.; Trpcevska, J.; Brinkienè, K. 2010. Investigation of wear resistance of high velocity oxy-fuel sprayed WCCo and $\mathrm{Cr}_{3} \mathrm{C}_{2}-\mathrm{NiCr}$ coatings, Mechanika (4)84: 75-79.

6. Mahler, F.H. 1972. Advanced Seal Technology, Rep. PWA-4372, Pratt \& Whitney Aircraft.

7. Coddet, Christian; Montavon, G.; Verdy, G. 2000. Mechanical characteristics of assemblies carried out by thermal spraying. Review CIT/Science of metallurgy and materials engineering, May 2000.

8. Wang, Hougong. 1996. Criteria for analysis of abradable coatings, Surface And Coatings Technology 79: 71-75.

9. Bounazef, Mokhtar; Guessama, Sofiane; El abbas Adda bedia. 2007. Blade protection and efficiency preservation of a turbine by a sacrificial material coating, Advanced Powder Technol. 18(2): 123-133.

10. Bounazef, Mokhtar; Djeffal, Ali; El Abbas Adda Bedia. 2009. Optimisation by behaviour modelling of a protective porous material, Computational materials Science 44: 921-928.

11. Hougong, Wang. 1996. Criteria for analysis of abradable coatings, Surface and Coatings Technology 79: 71-75.

12. Schmid, R.K.; Ghasnipoor, F.; Dorfman, M.; Wie, X. 2000. An overview of compressor abradable thermal sprays, in: c.c. Berndt (Ed), Surface Engineering International Thermal Spray Conference ITSC, May 2000, Montreal Canada, Via Applied Research. 406p.

13. Emery, A.F.; Wolak, J.; Etemad, S.; Choi, S.R. 1983. An experimental investigation of temperatures due to rubbing at the blade-seal interface in an aircraft compressor, Wear 91: 117-130.

14. Louvet, François. 2005. Designs of experiments, Expérimentique Edition, by François Louvet and Luc Delplanque (French edition).

15. Goupy, Jacques. 2005. Pratiquer les plans d'expériences, by Jacques Goupy, Edition Dunod (French Edition).

16. Goupy, Jacques; Greigton, Lee. 2009. Introduction aux plans d'expériences, French edition, Dunod edition. 300p.

17. Douglas C. Montgomery. 2009. Designs and analysis of experiments, 5th edition, Edition Amazon. 354p.

18. Wang, G. 1996. Criteria for analysis of abradable coatings, Surface and coatings technology 79: 71-75. 
A. Djeffal, M. Bounazef, E. A. Adda bedia

LAZERINIO INTERFEROMETRO PANAUDOJIMAS MENČIŲ DANGOS MEDŽIAGOS STRUKTŪRAI IR IŠSIDE்VĖJIMUI TIRTI

Rezi u m è

Iki šiol atlikti darbai parodè, kaip kai kurie parametrai veikia turbinų menčių dangos medžiagą. Ši medžiaga gali pakeisti hermetinius labirintus, kurie itaisomi rotoriaus ir turbinos vidiniame korpuse. Danga termiškai užpurškiama (Atmospheric Plasma Sprayning) ant vidinio turbinos paviršiaus. Ji naudojama menčių apsaugai, nes yra lengvai pašalinama ir neleidžia intensyviai dilti menčių viršūnems. Šiame darbe parodyta, kas atsitinka, kai šios medžiagos paviršių veikia darbo parametrai, kokia yra jos struktūra ir ypač kokie yra šiurkštumo parametrai, nuo kurių priklauso menčių dilimas. Pateikti modeliavimo rezultatai, gauti taikant eksperimentu planavimo metoda, detaliai interpretuojami paveikslais ir kreivèmis.
A. Djeffal, M. Bounazef, E. A. Adda bedia

\section{THE USE OF LASER INTERFEROMETER TO STUDY THE TEXTURE AND WEAR OF A PRESERVED BLADES MATERIAL}

S u m m a r y

The works carried out until now have shown how certain parameters act on the wear of turbine blades when they touch the protective seal material. This material is used to replace the air-tight labyrinths installed on the rotor and on the turbine internal casing. It is obtained by the process of thermal spraying (Atmospheric Plasma Spraying) and it is projected and deposed on the internal turbine envelop. It is used to protect the blades when it tore very easily without causing intense wear of the blades tip. In this work we showed how the surface of this material become in terms of operating parameters, what is its texture, and especially what are the different values of roughness parameters by linking it to the blades wear. The results obtaining by modelling using the method of experiments design are shown in the results part with detailed interpretations of the obtained graphs and curves.

Received January 20, 2011

Accepted June 30, 2011 